\title{
THE ANALYSIS OF THE VILLAGE LAW IMPLEMENTATION POLICY BY USING EDWARD III MODEL APPROACH IN GARUT
}

\author{
Ikeu Kania, Gugun Geusan, Leadya Raturahmi, Aceng Ulumudin, Erna Rustiana, \\ Mutiana Budiman \\ Faculty of Social and Politic Sciences, Garut University
}

\begin{abstract}
The equitable, prosperous, and independent village development that have not realized is the main problem of this study. The existence of Law no 6 of 2014 on Villages on the one hand is a hope but on the other hand becomes a challenge that must be built in a collaborative synergy between stakeholders or the elements of society in order to achieve the vision and mission of community independence and prosperity.

In Karangpawitan Subdistrict there are several obstacles in implementing Law No. 6 of 2014 on Villages. The obstacles are the lack of human resource who understands the laws, the lack of conducive communication, and complicated and unclear bureaucratic structure and disposition of the main duties and functions of each village officials which make the impact on nontransparent and unaccountable public service.

The method research used was qualitative approach with case study. The data was collected by doing observation and deep interview with the informant. The data analysis technique was Edward III Model approach by analyzing the factors that influence the implementation of policies, such as: (1) Communication; (2) Resources; (3) Disposition; and (4) Bureaucratic Structure.

The result of this research showed that there were several factors that should be improved and noticed in Dimension of Communication. The factors were goals and objectives, understanding and socialization form in order to achieve the goals and objectives that have been made. Furthermore, the Dimensions of Resources related to the competence of the village officials is the main problem and financial resources. The dimension of disposition is the character and characteristics possessed by implementers, such as lack of commitment, honesty, and ways of accepting the others' opinions. The last is the dimension of bureaucratic structure. It is the task, principal and function of the village officials which have not been optimal.
\end{abstract}

Keywords: Public Policy, Village Development, Public Welfare

\section{Introduction}

Constitution No.23 of 2014 shows that the focus of autonomy is on the regency / city area, with the consideration that regency / city area can be directly related with the society so that it is expected to understand more in fulfilling society's aspirations in implementing development. The inception of Constitution No.6 of 2014 about village that was legitimated in Jakarta on January 15th 2014 demands the village to improve village governance.

Village are demanded to implement the functions of village governance, and village development, village society's empowerment accurately. Village need to be able to make Rencana Pembangunan Jangka Menengah (RPJM) Desa, six years, and Village Work Planning (Rencana Kerja Desa), for one year, with the cost allocation in Village Revenue and Expenditure Budget (APB), that will be followed up by Village Regulation (PerDes) as a legal shelter of the implementation.

The important issue in current development is the slow development of implementation. It happens because of the bureaucratic weakness that is too extensive and the implementation of development program that is overlapping. Other effect is development plan that has been arranged and held by the government evidently is not appropriate with what society need. Another thing that has become village 
development weakness is the low capability of human resources in implementing village's policies, both in terms of governance and village empowerment.

According to Constitution No.6 of 2014, it is stated that in performing the duties, headman has a power to lead the implementation of village governance, manage village finances and assets, and establish village income and expenditure budgets. Besides that, headman also has an obligation of implementing the principles of village governance that are accountable, transparent, professional, effective and efficient, clean and free from collusion, corruption and nepotism.

As one of the policy form, in its implementation, the constitution about village sometimes deviates from the set objectives; therefore various approaches are needed to achieve successful policy implementation. The success of a policy implementation can be measured or seen from the process and the achievement of its objectives (output). The implementation of the policy will be successful if the executors obey to the instructions given by the upper level bureaucracy that establishes the policy.

This research aims to analyze the implementation of village constitution policy by using Edward III model approach. This approach stated that the success or failure implementation of policy is affected by: (1) Communication; (2) Resource; (3) Disposition; and (4) Bureaucracy structure. This approach is expected to capture the policy implementation or program from every aspect.

\section{Research Method}

The method used in this research was the qualitative method with the analysis approach of policy implementation model. The data was collected by observing and interviewing the key informant. In this case, the key informant is the head of the department of village community empowerment.

\section{Findings and Argument}

Certainly, formulated policies have specific purposes or targets that want to be achieved. The new target achievements will be realized if the policy has been implemented. The policy has to be implemented in order to find out whether the policy objectives can be achieved or not. Without an implementation, a formulated policy will be useless, since policy implementation is an important phase in the process of policy making. Furthermore, policy implementation can determine the effectiveness of the policy.

The policy implementation of village constitution in Garut was analyzed by using Edward III model approach. Then, based on the result of this research, it can be stated that policy implementation is affected by these several factors:

\section{a) Communication}

Communication is delivering the information between people. Policy communication means the process of delivering policy information from the policy makers to the policy implementers. The result of this policy implementation of village 
constitution research in Garut showed that from the aspect of communication has not been done well. It can be seen from its goals and objectives that have not been achieved. The policy about village has been socialized, but it has not been maximal. It is showed from the village officers who has not known and understood the content of the policy. The conducted socialization did not followed up continuously by doing several trainings like simulation using socialization media such as brochure or banner. It makes the implementers know only the outline.

Lack of socialization made the implementers (village officers) is able to manage budget for village development effectively and efficiently. Planning, organizing until implementation has not been done well. In fact, the arranged planning is not always in line with what has been formulated. Sometimes, policy implementation deviates from the stated objectives, therefore various approach needed to communicate the policy in order to achieve success policy implementation.

The factor of limited media used in delivering information is the cause of lack of understanding the stated objectives in the policy. In addition, the weak step of coordination done both scheduled and incidental among village officer affects the policy information become hard to get. Even though the success of policy implementation can be measured or seen from the process and the objective achievement (output).

\section{b) Resource}

Besides communication factors, Edward III stated that resource is factor that affect the performance of public policy. A policy will be more complete if there are resources that can ease policy execution in its implementation. The resources are human resource and financial resource. The policy implementation can be achieved if the resource adequate to support that activity. In other words, the policy implementer can be directly affected by source availability. This source availability can ease and expedite the policy implementation so that it can occur effectively.

The resource in policy implementation of village constitution research in Garut is still low both quality and quantity. $40 \%$ village officers were graduated from Junior High school, 10\% village officers were graduated from Senior High school, and 75\% village officers are bachelor. The lack of village officer education influence understanding of constitution content, especially in managing and reporting village financial, have not been appropriate with the real rules.

When Musrenbangdes was held, the village officers have not optimally participated. It is showed by the lack of suggestion, opinion, and other creative and innovative idea in planning. Likewise, in terms of managing village financial should be $70 \%$ for development costs and another $30 \%$ for village operational costs. But in reality, village operational costs used more than $30 \%$ out of budget.

\section{c) Disposition}

Disposition or the attitude of policy implementers is the third important factor of policy implementing approach. If the implementation of a policy wants to be 
effective, policy implementers must not only know what to do but also must have an ability in implementing it.

The implementation understanding of policy goals is an important thing. Successful policy implementation should be followed by the awareness of that whole policy. It means that a failed policy implementation is often caused by the implementer disobedience trough the policy. The implementers are failed doing the policy appropriately because they refuse the objectives of the policy. Conversely, the acceptance of policy's objectives can encourage the success policy implementation.

There are several reasons in refusing the policy. One of the reason is the policy's objectives that contradict with implementer personal value system. Thus, the policy implementer will find difficulties in implementing policies if they do not have basic attitude of their actions.

The tendency of village officers' behavior or characteristics as an implementer of policy has an important role in creating policy implementation that is compatible with the goals or objectives. The village officer attitude in Garut is quite good, especially in servicing the society. However, based on the observation, in several villages far from the district capital, many employees come late then make the people waiting for long to be served.

\section{d) Bureaucracy Structure}

This bureaucracy structure is absolutely needed because the complex policy demands contribution of many people. When the bureaucracy structure is not conducive with the exist policy, it will cause the resource become ineffective and inhibit the policy.

Two characteristics that boost better performance of bureaucracy structure are doing standard operating procedures (SOP) and fragmentation. SOP is a routine activity that enables the employee or policy implementer to do their activities as established standard (minimum standard that is needed by the people), while the implementation of fragmentation is an effort to disseminate the responsibilities of activities or employee activities among work units.

Based on the research result, it showed that the bureaucracy structure of several villages in Garut has not been formally good yet, since there are some villages that its bureaucracy structure has not been appropriate with the ideal number of employee. The ideal numbers of employee are 11 people. It inflicted the individual tasks and functions have not been done properly.

\section{Conclusion}

Based on the research result, it can be concluded that the policy implementation of village constitution in Garut there is still many factors that have to be concerned and improved. In the aspect of communication dimension, what should be improved are the goals and the objectives, understanding and socialization form done in order to achieve goals and objectives that have been made. Furthermore, in resource dimension the main problems are the village officer competence and financial resources. 


\section{Acknowledgment}

This research was supported by the faculty of Social and Politics in Garut University. We thank our colleagues from Garut University who provided insight and expertise that greatly assisted the research. We thank Abdulah Ramdhani, SE, M.Si (the dean of Social and Politics faculty in Garut University) for the support, comment, and assistance that greatly improved the manuscript.

\section{References}

Anderson, J. (1978). Public Policy Making. Chicago: Holt, Rinehart and Winston.

Azkia, M., \& Ghaffari, G. (2004). Rural development with emphasis on rural community of iran. Tehran Iran: Nai Publishing.

Dunn, W. N. (1994). Public Policy Analysis : An Introduction. New Jersey: Prentice-Hall, International, Inc., Englewood Cliffs. .

Dye, T. R. (1992). Understanding Public Policy. Seven Edition. New Jersey: Prentice-Hall, Inc.

Edwards III, G. (1980). Implementing Public Policy. Washington: Congressional Quarterly Press.

Falsolaiman, M., Sadeghi, H., \& Hajipur, M. (2014). Village development groups : model based on participations in achieving rural development. journal of geography and regional planning, $78-85$.

Lowe, P., Ray, C., Ward, N., Wood, D., \& Woodward, R. (2005). Participation in rural development center for rural economy publication. Departement of agriculture economics and food marketing: Universuty of newcastle.

Metter, V., \& Horn, V. (1975). The Policy Implementation Process : A Conceptual Framework. Department of Political Science Ohio State University. Administration and Society, Vol. 6 No 4 February.

Ripley, R. B., \& Franklin. (1986). Policy Implementation and Bureaucracy. Chicago: The Dorsey Press.

Udhoji, C. J. (1981). The African Public servant: As a Publik Policy in Africa. Addis Abeba: African Assosiation for Public Administration and Management. 